This item was submitted to Loughborough's Research Repository by the author.

Items in Figshare are protected by copyright, with all rights reserved, unless otherwise indicated.

\title{
Activation of thin film CdTe solar cells using a cadmium bromide treatment
}

PLEASE CITE THE PUBLISHED VERSION

https://doi.org/10.1109/pvsc.2018.8547756

PUBLISHER

(c) IEEE

VERSION

AM (Accepted Manuscript)

LICENCE

CC BY-NC-ND 4.0

REPOSITORY RECORD

Greenhalgh, R.C., Ali Abbas, Amit Munshi, Tushar M. Shimpi, Kurt L. Barth, Walajabad S. Sampath, Jake W. Bowers, and Michael Walls. 2019. "Activation of Thin Film Cdte Solar Cells Using a Cadmium Bromide Treatment”. figshare. https://hdl.handle.net/2134/37227. 


\title{
Activation of Thin Film CdTe Solar Cells Using a Cadmium Bromide Treatment
}

\author{
R.C.Greenhalgh ${ }^{1}$, A. Abbas $^{1}$, A. H. Munshi ${ }^{2}$, T. M. Shimpi ${ }^{2}$, K.L.Barth ${ }^{2}$, W. S. Sampath ${ }^{2}$ \\ J. W. Bowers ${ }^{1}$ and J. M. Walls ${ }^{1}$ \\ ${ }^{1}$ CREST, Loughborough University, Loughborough, United Kingdom, LE11 3TU \\ ${ }^{2}$ NSF I/UCRC for Next Generation Photovoltaics, Colorado State University, Fort Collins, \\ CO 80526 United States
}

\begin{abstract}
The activation of CdTe with a cadmium chloride annealing treatment is a vital step in the fabrication of high efficiency solar cells. Thin film MZO/CdTe cells have been activated using $\mathrm{CdBr}_{2}$ instead of $\mathrm{CdCl}_{2}$ with a lower activation process temperature. Using this method, $\mathrm{CdBr}_{2}$ does activate the cell as revealed by $\mathrm{J}-\mathrm{V}$ and EQE measurements. TEM and EDX elemental maps from device cross-sections confirm that bromine is present in the grain boundaries. TEM shows that the treatment removes stacking faults at $425{ }^{\circ} \mathrm{C}$. $\mathrm{CdBr}_{2}$ treatment resulted in a relatively modest conversion efficiency of $5.49 \%$ when treated at $375{ }^{\circ} \mathrm{C}$. Nevertheless, the experiments shed further light on the mechanisms involved in the activation.
\end{abstract}

Keywords - CdTe, CdBr2, activation, TEM, EQE, EDX

\section{INTRODUCTION}

Cadmium telluride (CdTe) is an ideal photovoltaic material due to its bandgap of $\sim 1.5 \mathrm{eV}$ which is close to the maximum theoretical efficiency according to Shockley-Queisser, with a thin film of $\sim 2 \mu \mathrm{m}$ required to fully absorb the light in the solar spectrum [1].

An activation treatment involving $\mathrm{CdCl}_{2}$ is required to improve the efficiency of CdTe solar cells. The $\mathrm{CdCl}_{2}$ treatment has been observed to recrystallize the CdTe grains, remove planar defects such as stacking faults and decorate grain boundaries [2] , [3]. The CdTe grain boundaries act as recombination centres, and the chlorine passivates these, significantly improving the efficiency of the device [4].

Studies changing the toxic cadmium cation in the process to other chloride sources, including sodium, potassium, magnesium, and hydrogen [5] , [6] have shown that these can be almost as effective in activating $\mathrm{CdTe}$ as $\mathrm{CdCl}_{2}$, and are much less toxic. However, little research has been performed on alternatives to the chlorine anion. The introduction of fluorine into the activation process via $\mathrm{CdF}_{2}$ has been investigated [7], however due to the reactivity of fluorine and

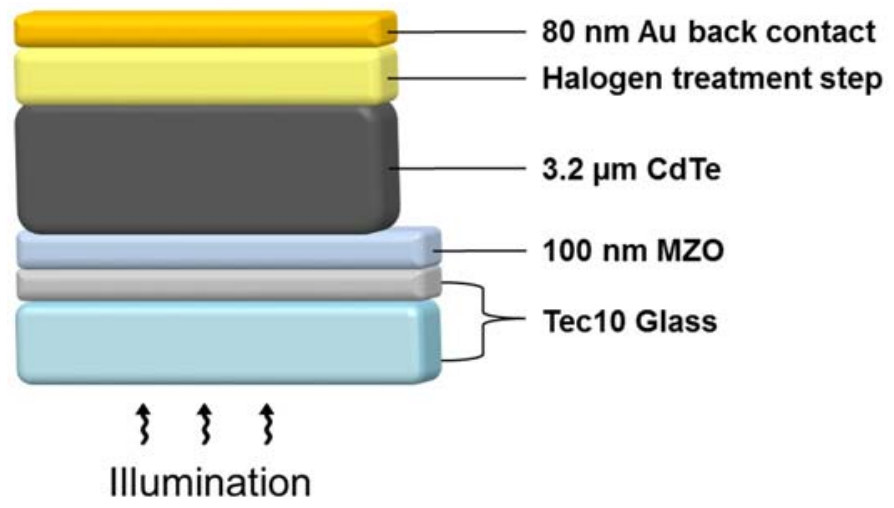

Fig. 1. The MZO/CdTe Device Architecture toxicity of $\mathrm{CdF}_{2}$ this is unsafe and unlikely to be scalable industrially.

Electrically, the chlorine has been theorized to make the grain boundaries less p-type than the grain bulk [8]. This improves carrier collection as grain boundaries may act as a segregated conduction pathway for electrons due to local electric fields [4]. However, the predominant effect of chlorine is passivation of dangling bonds at grain boundaries and removal of planar defects[3], [9].

In this study, the use of $\mathrm{CdBr}_{2}$ during the activation treatment is investigated; and the structural rearrangement caused by $\mathrm{CdBr}_{2}$ and its effect on conversion efficiency. We also report on a preliminary investigation of the effect of varying some processing conditions.

\section{EXPERIMENTAL DETAILS}

The devices used in this study were produced on $3 \mathrm{~mm}$ thick 79 x 91 mm Fluorine doped Tin Oxide (FTO) coated soda lime glass substrates (NSG Pilkington, TEC 10). See Figure 1 for the cell architecture used. The Magnesium doped Zinc Oxide (MZO) buffer layer was deposited by Radio Frequency (RF) - magnetron sputtering [8] and the CdTe layer by close space sublimation [9]. The activation treatments were performed in a graphite box set up in a tube furnace as shown schematically in Figure 2. $\mathrm{CdBr}_{2}$ material (99.9985 \% metals basis, ultra-dry Alfa Aesar) was used in a graphite box. The temperature of the source was between 375 ${ }^{\circ} \mathrm{C}$ and $425^{\circ} \mathrm{C}$. This temperature range was chosen because the vapour pressure of $\mathrm{CdBr}_{2}$ at $375^{\circ} \mathrm{C}$ is approximately the same as the vapor pressure of $\mathrm{CdCl}_{2}$ at $450{ }^{\circ} \mathrm{C}$ [10]. It has been observed that the chlorine in the chlorine doped grain boundaries is easily released above $450{ }^{\circ} \mathrm{C}$ [11]. It was assumed that, if $\mathrm{CdBr}_{2}$ had a higher vapour pressure than

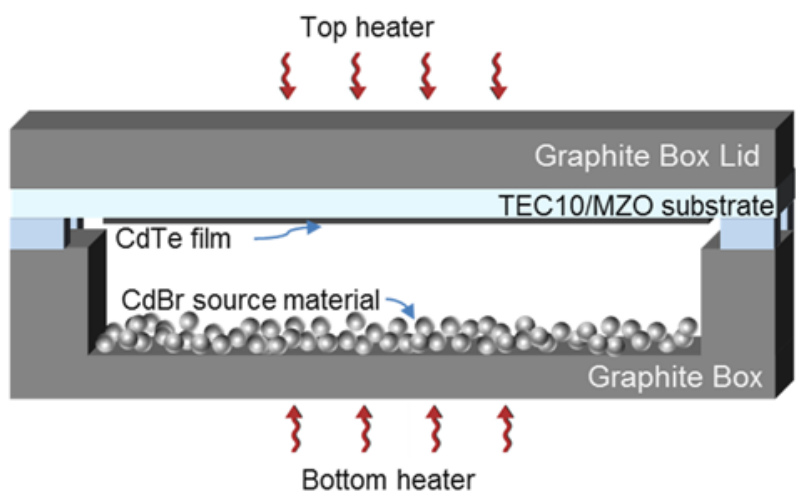

Fig. 2. Activation treatment set up with $\mathrm{CdBr}_{2}$ in a vacuum tube furnace 

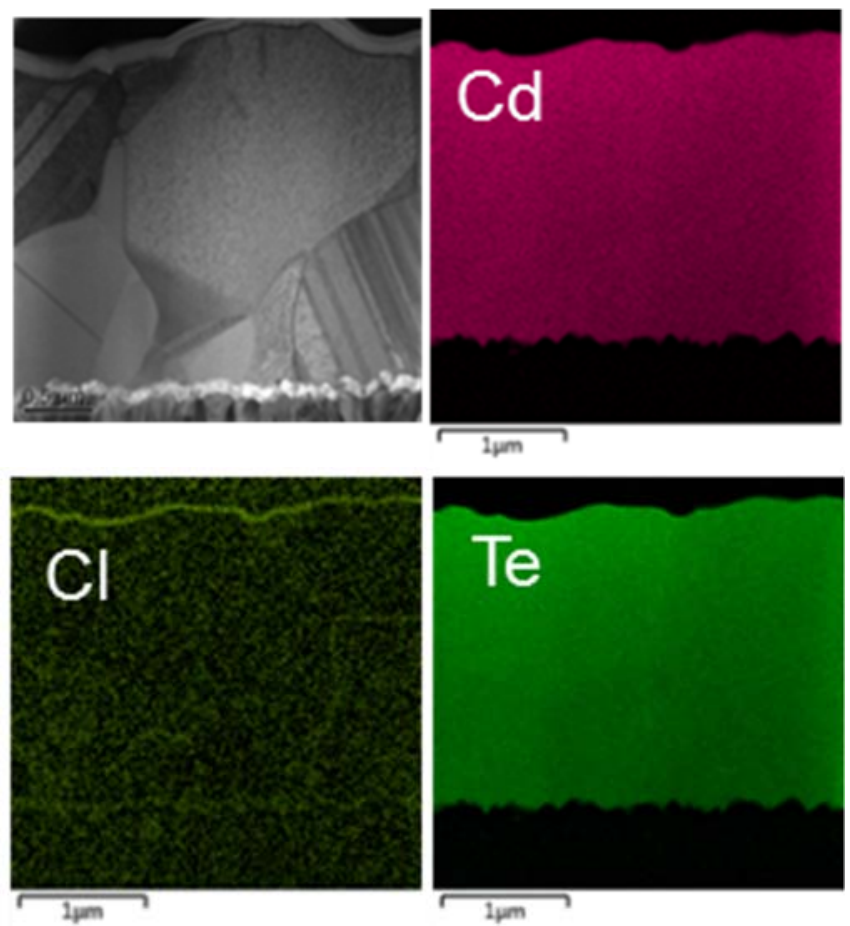

Fig. 3. TEM images and EDX elemental maps of a $\mathrm{CdCl}_{2}$ treated device

$\mathrm{CdCl}_{2}$, the bromine in the bromine doped CdTe would be more easily released from the CdTe film at a lower temperature, therefore a lower temperature would be preferable.

The tube furnace was pumped down to approximately 100 mTorr. Nitrogen was used to flush the system, the pump and $\mathrm{N}_{2}$ lines were closed, with the furnace maintained at a 200 Torr. The furnace was heated to $125^{\circ} \mathrm{C}$, pumped and flushed with nitrogen to degas the $\mathrm{CdBr}_{2}$. It was then heated to 300 ${ }^{\circ} \mathrm{C}$ and held for 5 minutes to equilibrate. The temperature was then raised to the specified treatment temperature and dwelled at the specified time. The furnace was then left to cool at a constant pressure of $400 \mathrm{~T}$ and the samples removed at $50^{\circ} \mathrm{C}$.

$80 \mathrm{~nm}$ of gold (wire, 99.999\%, Testbourne) was evaporated with an in-house system to form the back electrode. A mask was used to give a contact area of $0.25 \mathrm{~cm}^{2}$.

Specimens for Transmission Electron Microscopy (TEM) were prepared by Focused Ion Beam (FIB) milling. TEM was carried out using a FEI Technai F20, equipped with an Oxford Instruments X-max N8 TLE SDD for energy dispersive Xray Spectroscopy (EDX). The $\mathrm{J}-\mathrm{V}$ measurements were performed using an in-house solar simulator set up with a xenon arc lamp and AM1.5 filter. The external quantum efficiency (EQE) measurements were acquired with a Bentham PVE300 system. and performed at $0 \mathrm{~V}$ bias with an A.M.1.5 white light bias, with a spectral resolution of $5 \mathrm{~nm}$.

\section{RESULTS AND DISCUSSION}

Fig. 4 shows the EDX maps obtained from the $\mathrm{CdBr}_{2}$ treated cells. The bromine map shows segregation to the grain boundaries as has also been observed with chlorine (see Fig. 3) [3],[12], [13]. This indicates that $\mathrm{Cl}$ and $\mathrm{Br}$ behave similarly in the CdTe grain boundaries. The zinc and oxygen
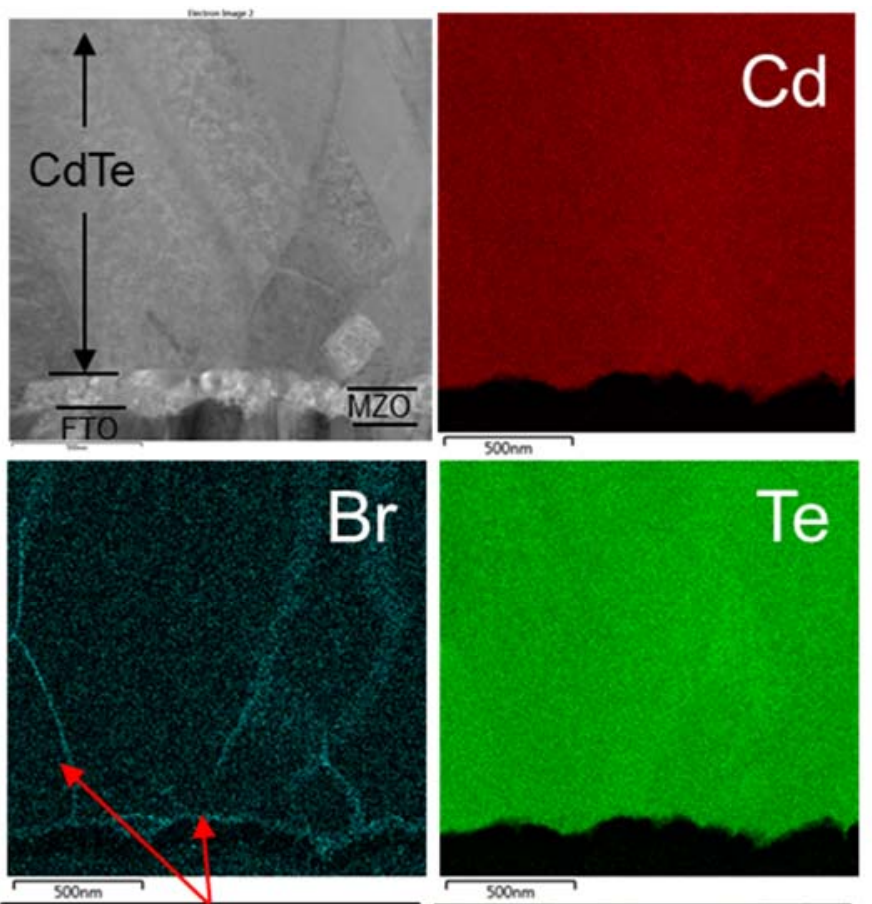

\section{Br segrates along grain boundaries and $\mathrm{MZO} / \mathrm{CdTe}$ interface}

Magnesium and Zinc appear to be stable in the MZO layer and show minimal diffusion into $\mathrm{CdTe}$
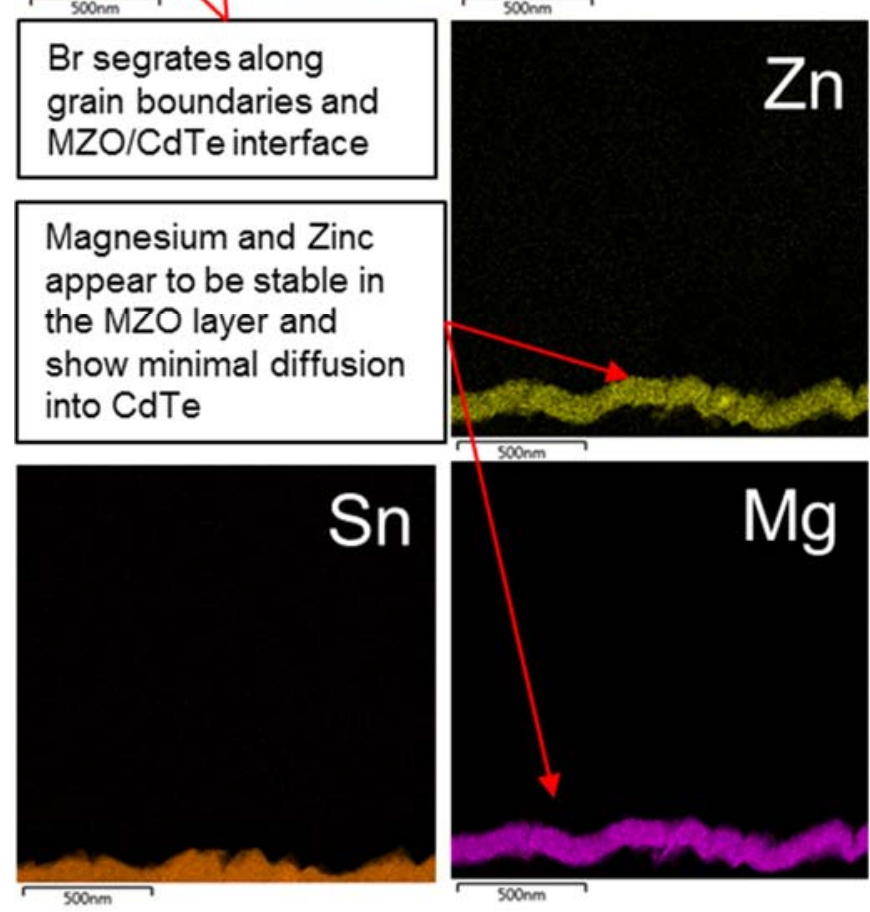

Fig. 4. EDX elemental map of $\mathrm{CdBr}_{2}$ treated device

in the MZO appear to be stable following the $\mathrm{CdBr}_{2}$ treatment, showing minimal diffusion into the CdTe.

The TEM image of the $425^{\circ} \mathrm{C} \mathrm{CdBr}_{2}$ treated cells shown in Fig. 5 structurally resembles the appearance of a device which has been fully treated with $\mathrm{CdCl}_{2}$. Full depth, 1 micron wide recrystallized grains are observed. These grains are free from stacking faults and twins are present which are also observed in $\mathrm{CdCl}_{2}$ treated cells and are thought to be electrically benign [3],[14]. The untreated device shown in Fig. 5 has stacking faults in almost all of the grains, narrow grains, and smaller grains present near the MZO/CdTe interface; as observed previously in CdTe [3]. The TEM image of the $375^{\circ} \mathrm{C} \mathrm{CdBr}$ treated cell shows twins, a reduced number of stacking faults, and many small grains at the interface, and larger grain sizes than the untreated grains. This 

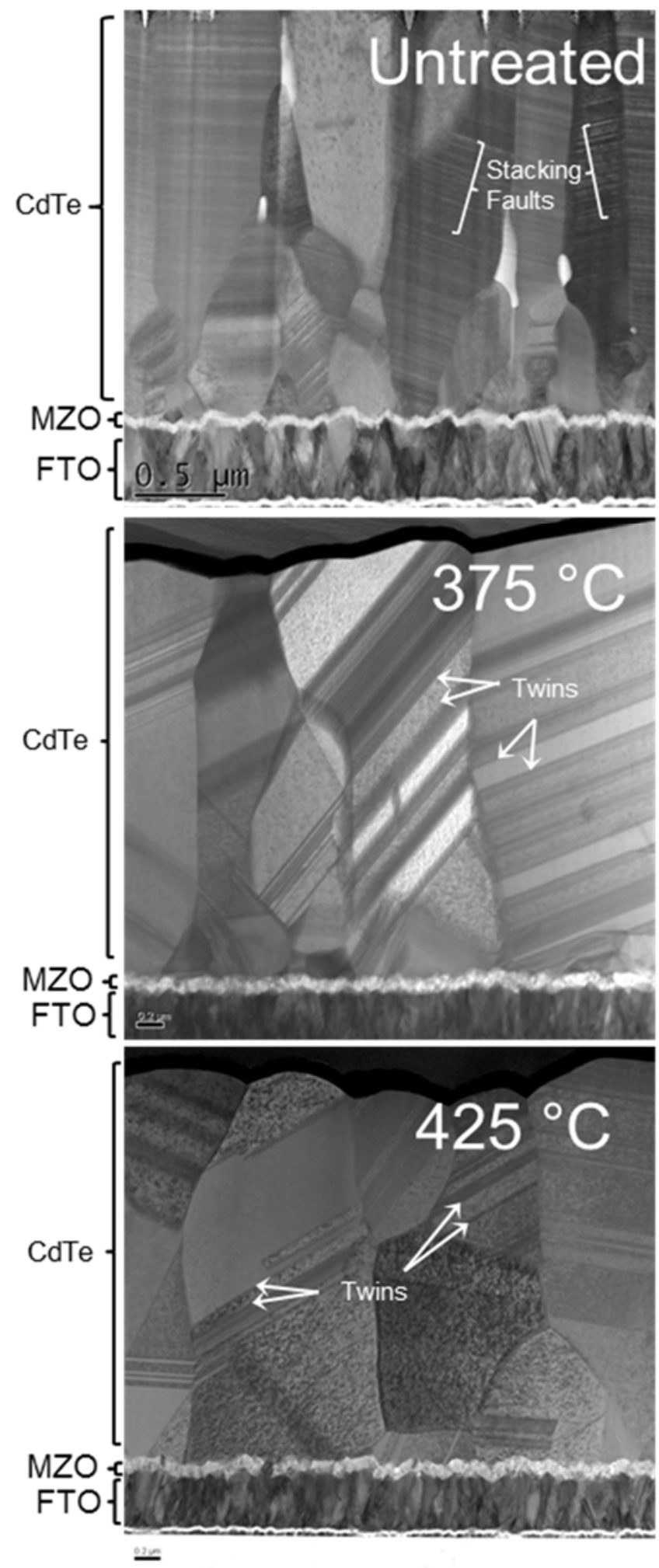

Fig. 5. Dark Field TEM cross-sections of CdTe untreated, treated at $375{ }^{\circ} \mathrm{C}$ with $\mathrm{CdBr}_{2}$ for 15 minutes and treated at $425{ }^{\circ} \mathrm{C}$ for 15 minutes. The treated cells are free of voids.

indicates partial recrystallization as there is a reduction of defects in the $\mathrm{CdBr}_{2}$ treated device when compared to asdeposited samples. These are preliminary results, and it is expected that the process will improve further with optimization.

The $375^{\circ} \mathrm{C} \mathrm{CdBr}_{2}$ treated device in this work has an efficiency of 5.49\% (Fig. 7) with just partial recrystallisation,

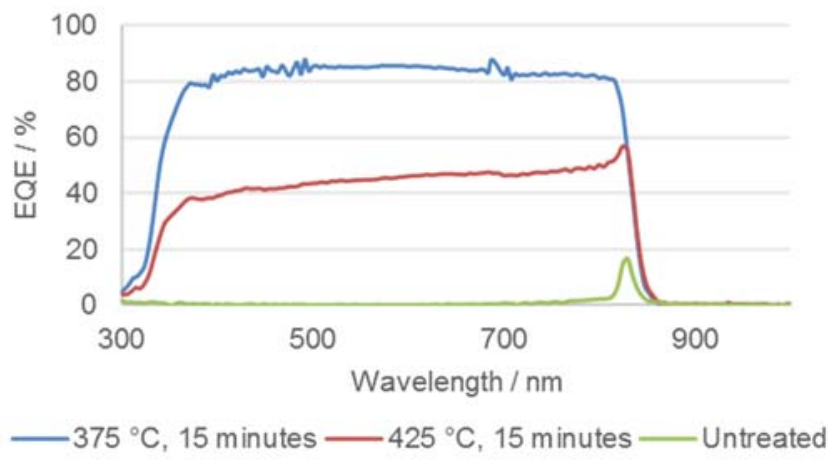

Fig. 6. EQE spectra of the untreated sample and samples treated at $375^{\circ} \mathrm{C}$ or $425^{\circ} \mathrm{C}$ for 15 minutes

TABLE I

Current Densities Of Treated And Untreated Devices FROM EQE MEASUREMENTS

\begin{tabular}{l|l} 
TREATMENT & CURRENT DENSITY \\
\hline $3755^{\circ} \mathrm{C}, 15 \mathrm{~min}$ & $24.48 \mathrm{~mA} / \mathrm{cm}^{2}$ \\
$4255^{\circ} \mathrm{C}, 15 \mathrm{~min}$ & $13.64 \mathrm{~mA} / \mathrm{cm}^{2}$ \\
Untreated & $0.39 \mathrm{~mA} / \mathrm{cm}^{2}$
\end{tabular}

which is greater than the efficiency for the process at $425^{\circ} \mathrm{C}$ where a more pronounced structural improvement was observed. This indicates that the bromine may be electrically passivating the grain boundaries similar to chlorine, [3],[4],15]. However, further electrical characterization will be required to explain this observation. The EQE spectra shown in Fig. 6 comparing the treatment at $375{ }^{\circ} \mathrm{C}$ with the untreated cell shows a drastic increase in the EQE to $80 \%$ between wavelengths $375-816 \mathrm{~nm}$. The untreated cell has a 0\% EQE response between $375-715 \mathrm{~nm}$, with a slight increase to $3.6 \%$ at $810 \mathrm{~nm}$ and a peak at $830 \mathrm{~nm}$. The 375 ${ }^{\circ} \mathrm{C}$ treated device has an EQE response similar to $\mathrm{CdCl}_{2}$ treated $\mathrm{MZO} / \mathrm{CdTe}$ devices [12]. This is surprising given that it has only undergone a partial recrystallisation, and indicates that bromine is electrically active without the need for full microstructural rearrangement. The $425{ }^{\circ} \mathrm{C}$ treated cell which appears to be fully recrystallized has a much lower $\mathrm{EQE}$ response, so may be overtreated in terms of bromine in the boundaries and at the junction.

The $\mathrm{J}_{\mathrm{sc}}, \mathrm{V}_{\mathrm{oc}}$ and Fill Factor (FF) are lower for $\mathrm{CdBr}_{2}$ in this study when compared with optimized $\mathrm{CdCl}_{2}$ treated cells. As an example, an optimized $\mathrm{CdCl}_{2}$ treated $\mathrm{MZO} / \mathrm{CdTe}$ cell, with a Cu doped optimized back contact has J-V parameters of: $\mathrm{J}_{\mathrm{sc}}=26.8 \mathrm{~mA} / \mathrm{cm}^{2}, \mathrm{~V}_{\text {oc }}=863 \mathrm{mV}$ and $\mathrm{FF}=79.2 \%$ [16]. The $375{ }^{\circ} \mathrm{C} \mathrm{CdBr}_{2}$ treated $\mathrm{MZO} / \mathrm{CdTe}$ device with an unoptimized gold back contact in this study showed a maximum current density of $24.48 \mathrm{~mA} / \mathrm{cm}^{2}$ from EQE data (See TABLE ), a $\mathrm{V}_{\text {oc }}$ of $570 \mathrm{mV}$ and a $\mathrm{FF}$ of $47 \%$ from J-V data (Fig. 7). This is a significant improvement on the untreated device with an EQE current density of $0.39 \mathrm{~mA} / \mathrm{cm}^{2}$ and the $\mathrm{V}_{\text {oc }}$ from J-V of $280 \mathrm{mV}$ and efficiency of $0.07 \%$. Further optimization of the activation process and device finishing should lead to improvements in these parameters. This is a promising start for further research into passivation with bromide compounds. 


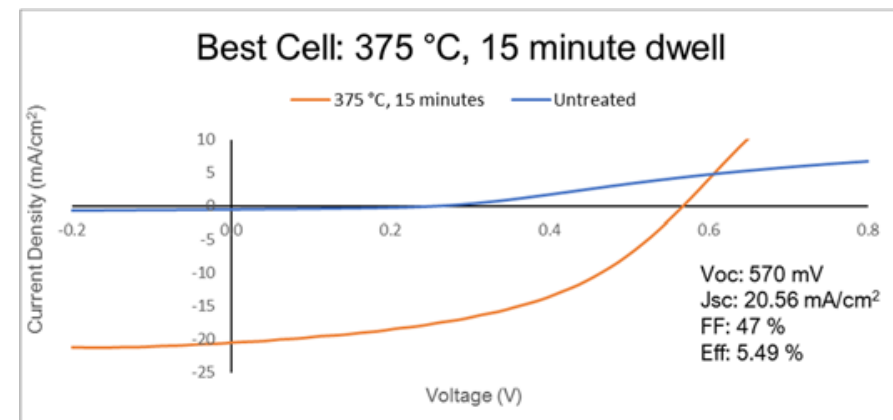

Fig. 7. J-Vcurve of the $5.49 \%$ efficient $\mathrm{CdBr}_{2}$ device treated at 375 ${ }^{\circ} \mathrm{C}$ with a 15 minute dwell, with an untreated device for comparison

\section{CONCLUSIONS}

In conclusion, it has been shown that activation with $\mathrm{CdBr}_{2}$ introduces the halogen into the grain boundaries of the $\mathrm{MZO} / \mathrm{CdTe}$ device. The bromine annealing process causes recrystallization of the CdTe absorber layer and the removal of stacking faults. Efficiencies of 5.49\% have been obtained. The experiments show that the passivation effects observed following a chlorine treatment can also be observed following treatment with bromine. A preliminary study has shown that iodine also causes cell activation.

The focus for further work will be to observe if the full microstructural rearrangement caused by treatment with $\mathrm{CdCl}_{2}$ can be achieved with $\mathrm{CdBr}_{2}$. Following this, the authors aim to compare processing temperature and electrical effect of the bromine on the CdTe grain boundaries.

\section{ACKNOWLEDGEMENTS}

The Loughborough University authors are grateful to UKERC for financial assistance through the EPSRC Supergen SuperSolar Hub and a studentship with the CDT in New and Sustainable Photovoltaics; and the CSU authors to the NSF I/UCRC for next generation photovoltaics and NSF AIR-RA.

\section{REFERENCES}

[1] F. V Wald, “Applications of CdTe. A review,” Rev. Phys. Appl., vol. 12, no. 2, pp. 277-290, 1977.

[2] A. Romeo, D. L. B. Ètzner, H. Zogg, and A. N. Tiwari, "Recrystallization in CdTe/CdS," Thin Solid Films, vol. 361-362, pp. 420-425, 2000.

[3] A. Abbas et al., "The effect of cadmium chloride treatment on close-spaced sublimated cadmium telluride thin-film solar cells," in IEEE Journal of Photovoltaics, 2013, vol. 3, no. 4, pp. 1361-1366.
[4] C. Li et al., "Grain-boundary-enhanced carrier collection in CdTe solar cells,” Phys. Rev. Lett., vol. 112, no. 15, pp. 1-5, 2014.

[5] B. Maniscalco et al., "The activation of thin film CdTe solar cells using alternative chlorine containing compounds,” Thin Solid Films, vol. 582, pp. 115-119, 2015.

[6] J. D. Major, R. E. Treharne, L. J. Phillips, and K. Durose, "A low-cost non-toxic post-growth activation step for CdTe solar cells,” Nature, vol. 511, pp. 334-337, Jul. 2014.

[7] O. K. Echendu and I. M. Dharmadasa, "The effect on CdS/CdTe solar cell conversion efficiency of the presence of fluorine in the usual $\mathrm{CdCl}_{2}$ treatment of CdTe," Mater. Chem. Phys., vol. 157, pp. 39-44, 2015.

[8] M. Tuteja et al., "Direct Observation Of $\mathrm{CdCl}_{2}$ TreatmentInduced Grain Boundary Carrier Depletion in CdTe Solar Cells Using Scanning-Probe Microwave Reflectivity Based Capacitance Measurements,” J. Phys. Chem. C, vol. 120, no. 13, pp. 7020-7024, 2016.

[9] A. Lindström, M. Klintenberg, B. Sanyal, and S. Mirbt, "Cl-doping of Te-rich CdTe: Complex formation, selfcompensation and self-purification from first principles," AIP Adv., vol. 5, p. 87101, Aug. 2015.

[10] Kyzysztof Skudlarski, Jerzy DudeK, and Jan Kapala, "Thermodynamics of sublimation of cadmium halides investigated by the mass-spectrometric method,” J. Chem. Thermodyn., vol. 19, pp. 857-862, 1987.

[11] A. Abbas et al., "The effect of a post-activation annealing treatment on thin film CdTe device performance," in 2015 IEEE 42nd Photovoltaic Specialist Conference (PVSC), 2015, pp. 1-6.

[12] A. H. Munshi et al., "Polycrystalline CdTe photovoltaics with efficiency over 18\% through improved absorber passivation and current collection," Sol. Energy Mater. Sol. Cells, vol. 176, pp. 9-18, 2018.

[13] M. Terheggen et al., "Structural and chemical interface characterization of CdTe solar cells by transmission electron microscopy,” Thin Solid Films, vol. 431-432, pp. 262-266, May 2003.

[14] S.-H. Yoo, K. T. Butler, A. Soon, A. Abbas, J. M. Walls, and A. Walsh, "Identification of critical stacking faults in thin-film CdTe solar cells,” t. Appl. Phys. Lett.., vol. 1051, no. 10, pp. 62104-1304, 2014.

[15] H. P. Yoon et al., "High-resolution local current measurement of CdTe solar cells," Conf. Rec. IEEE Photovolt. Spec. Conf., pp. 3217-3219, 2012.

[16] J. Sites, A. Munshi, J. Kephart, D. Swanson, and W. S. Sampath, "Progress and Challenges with CdTe Cell Efficiency,” 43rd IEEE Photovolt. Spec. Conf., pp. 36323635, 2016. 